Dorota Gradalska*

Kraków

\title{
Dziela apostolskie w duchu Opus Dei
}

2 listopada 1989 roku na zaproszenie arcybiskupa Kazimierza Majdańskiego przybyli do Polski ksiądz Stefan Moszoro-Dąbrowski z Argentyny oraz ksiądz Rafael Mora z Hiszpanii po to, aby rozpoczać stałą pracę apostolską i dotrzeć z nauką św. Josemaríi Escrivy do wszystkich ludzi. Niespełna rok później w Warszawie otworzyli oni pierwszy ośrodek, w którym wraz z garstką wiernych świeckich rozpoczęli organizację kolejnych domów formacyjnych. Następne lata zaowocowały powstaniem ośrodków w Warszawie, Szczecinie, Krakowie oraz Poznaniu, nad którymi opiekę duszpasterską roztoczyło Opus Dei. Dziś praca formacyjna Opus Dei zakorzeniła się już w Polsce i objęła niemal cały kraj.

\section{Opus Dei - poslannictwo i organizacja}

Opus Dei (pol. Dzieło Boże; pełne brzmienie oficjalnej nazwy to Prałatura Świętego Krzyża i Opus Dei) jest międzynarodową organizacją apostolską, istniejącą w ramach Kościoła katolickiego, poprzez którą cały Kościół (czyli Kościół powszechny) dokonuje w swoim wnętrzu ,specjalnych zadań duszpasterskich". Założył ją w 1928 roku hiszpański ksiądz Josemaría Escrivá de Balaguer, zmarły w 1975 roku, a kanonizowany przez papieża Jana Pawła II w 2002 roku. Jest jedyna, jak do tej pory, prałaturą personalną Kościoła katolickiego, powołaną na mocy konstytucji apostolskiej Jana Pawła II Ut sit w 1982 roku. Obecnie Opus Dei liczy około 85000 zde-

* Mgr Dorota Grądalska jest doktorantką w Zakładzie Teorii Wychowania i Opieki w Instytucie Pedagogiki Uniwersytetu Jagiellońskiego w Krakowie. 
klarowanych członków, z których 98\% to świeccy - kobiety i mężczyźni, w większości żyjący w małżeństwach, a część z tej grupy to celibatariusze pozostający do dyspozycji Dzieła; pozostałe 2 proc. stanowią księża. Liczbę wiernych w Polsce szacuje się na 500 osób. Gdyby jednak policzyć sympatyków, współpracowników i ludzi pozostających w kontakcie z Dziełem, to należałoby tę liczbę zwielokrotnić do 4-5 tysięcy ${ }^{1}$.

Jak zaznacza G. Romano, misja Opus Dei nie wynika z założeń instytucjonalnych, lecz z posłannictwa od Boga, realizacji którego ma służyć struktura formalna. Kwestia pozycji Dzieła w Kościele jest - zdaniem badacza - przede wszystkim sprawą ducha i charyzmatu założycielskiego. W tym sensie Opus Dei jawi się jako „bezbrzeżne morze” - jego posłannictwo bowiem nie uznaje granic i skierowane jest do każdego wiernego świeckiego. Dlatego wierni Prałatury, którzy są związani z Dziełem na mocy powołania nadprzyrodzonego wyrażonego umową ${ }^{2}$, nie są jego jedynymi odbiorcami. Uważa się ich za osoby oddane całkowicie Bogu, do których posłannictwo już dotarło, by przynosić w otoczeniu, w którym żyją na co dzień, owoce świętości i apostolstwa osobistego ${ }^{3}$.

Syntezy na temat podstaw duchowości Dzieła dostarcza lektura pierwszego rozdziału Statutów Pratatury Opus Dei, które w wielu miejscach zawierają fragmenty $\mathrm{z}$ pierwszych pism Założyciela. $\mathrm{Z}$ dokumentu tego wynika, że cel Prałatury jest podwójny - apostolski i duszpasterski. Z jednej strony Prałat ${ }^{4}$ za pomocą swoich duchownych rozwija szczególną pracę duszpasterska, polegającą na opiekowaniu się wiernymi korzystającymi ze środków formacyjnych Opus Dei i podtrzymywaniu ich w wypełnianiu powziętych zobowiązań życia chrześcijańskiego, z drugiej zaś Prałatura (duchowni i świeccy, wspólnie i nierozerwalnie połączeni) swym apostolstwem wśród wszystkich środowisk społecznych realizuje potrzebę uświadamiania „powszechnego wezwania do świętości” oraz „apostolstwa”.

1 Źródło danych: strona internetowa Opus Dei www.opus.dei.pl oraz M. Czerska, Opus Dei: „Polska to raj, ludzie sami do nas przychodza”, portal fronda.pl (dostęp 20.05.2013).

${ }^{2}$ Przyłączenie do Opus Dei następuje przez wymianę oświadczenia woli, co według normy III Konstytucji apostolskiej Ut sit oraz kanonu 296. Kodeksu Prawa Kanonicznego uprawnia do mówienia o zawarciu konwencji bądź umowy.

${ }^{3}$ Por. G. Romano, Opus Dei. Posłannictwo, inicjatywy, ludzie, Częstochowa 2002, s. 25.

${ }^{4}$ Według prawa Kościoła katolickiego na czele prałatury stoi prałat, jej właściwy ordynariusz, mianowany przez Papieża, konsekrowany na biskupa lub nie, kierujący nią na mocy jurysdykcji kościelnej. Obecnym Prałatem Opus Dei jest bp Javier Echevarria (urodzony w Madrycie w 1932 roku). Objął on urząd w 1994 roku po bp Alvaro del Portillo, następcy Josemaríi Escrivy po jego śmierci w 1975 roku.

${ }^{5}$ G. Pindur, Wstęp, w: J. Escrivá, Rozmowy z Prałatem. Kochać Kościót, KatowiceZąbki 2006, s. 22. 
J. Domaradzki zauważył, że św. Josemaría Escrivá, mówiąc o doktrynie Dzieła, używał szczególnego języka - w oparciu o istniejące definicje tworzył nowe pojęcia, które silnie zintegrowane z tradycją Kościoła dawały jednocześnie wyraz odnowicielskiego charakteru ruchu Opus Dei ${ }^{6}$. Tak skonstruowane pojęcia najlepiej opisywały i tworzyły Dzieło już u jego początków. Przypominając o „powszechnym powołaniu do świętości”, ksiądz Escrivá wskazywał jednocześnie drogę do jej osiagnnięcia, jaką jest przemienianie w modlitwę i świętość realizacji codziennych zajęć i obowiązków. Proponował nie tyle „duchowość świeckich” realizowaną poprzez te same środki, które stosują zakonnicy i duchowni, co „duchowość dla świeckich”, odnoszącą się do konkretnego „tu i teraz” człowieka na ziemi. Miejscem, w którym człowiek winien wzrastać w świętości jest jego otoczenie - rodzina, środowisko pracy, krąg przyjaciół czy napotykanych osób, a sposobami jej osiagania - dobre wypełnianie roli społecznej oraz wprowadzanie w najbliższe środowiska ducha pokoju i radości.

Punkt 863 Katechizmu Kościoła katolickiego przypomina, że powołanie chrześcijańskie jest również ze swojej natury powołaniem do apostolstwa. W Nocie Kongregacji Nauki Wiary została podkreślona pilna potrzeba tego, by każdy chrześcijanin rozpoznał ewangelizację jako swoją powinność i prawo, wynikające ze chrztu? . Osobista świętość nierozerwalnie związana jest więc ze świadczeniem o Chrystusie i staraniami o rozszerzanie Jego Królestwa po całej ziemi ${ }^{8}$. Tak rozumiane apostołowanie skutkuje uświęcaniem innych ludzi, a pośrednio i całego społeczeństwa. Jednak tak jak ,świętość” i inne pojęcia konstytuujące Ducha Dzieła (np. „dusza kapłańska”, ,jedność życia”, „kontemplacja w świecie”, „laikat” etc.) ma ono charakter jedynie przejawu, nie zaś fundamentu duchowości. Tym bowiem fundamentem jest „dziecięctwo Boże”. Poczucie, że jest się ukochanym dzieckiem Boga było dla Escrivy najważniejsze. To właśnie to doświadczenie prowadzi do „przebóstwienia" życia oraz osobowości człowieka i sprawia, że naśladuje on Jezusa Chrystusa a własne czyny przemienia w instrument apostolstwa9.

Wszelkie ludzkie działanie - nauczał Escrivá - winno być prowadzone przez kontemplację i do niej zarazem zmierzać. „Masz kroczyć swoją drogą jako człowiek czynu... z powołaniem kontemplacyjnym" - pisał

${ }^{6}$ Zob. J. Domaradzki, Ethos pracy w doktrynie i praktyce Opus Dei, Kraków 2010, s. $175-180$.

${ }^{7}$ Kongregacja Nauki Wiary, Nota doktrynalna na temat pewnych aspektów ewangelizacji, 3 XII 2007 r., nr 10.

${ }^{8}$ Por. Sobór Watykański II, Dekret Apostolicam actuositatem, w: tenże, Konstytucje. Dekrety. Deklaracje, Poznań 2002, nr 2, s. 378 oraz Katechizm Kościoła katolickiego, Poznań 2002, nr 2 oraz 221.

9 Por. R. G. Pérez, Opus Dei. Próba wyjaśnienia, Lublin 1998, s. 70. 
w Bruzdzie ${ }^{10}$. „Kontempluj pracując”- przypominał w innym miejscu ${ }^{11}$. Kontemplacja była nie tylko procesem rozumowym, lecz przede wszystkim „skupieniem” serca i poddaniem całej osoby tchnieniu Ducha Świętego. Ojciec Dzieła wspominał o sercu jako streszczeniu i źródle, uzewnętrznieniu i fundamencie ludzkich działań. Wzywał do jego „mądrości” - to w nim bowiem następuje synteza myśli, słów i czynów, które ukierunkowuja człowieka - duchowo i cieleśnie - na to, co dobre ${ }^{12}$. W ten oto sposób Święty wytyczył podstawy dla ludzkiej aktywności we wszystkich jej wymiarach. Kontemplacja, o której mówił, uwyraźnia się, kiedy jest zastosowana do spraw materialnych. Opiera się na ludzkich możliwościach, ale korzysta z nich zawsze w perspektywie nadprzyrodzonej (zob. rozdział 3.1).

\section{Apostolstwo wiernych Pralatury}

Można wymienić dwa kierunki, w jakich wierni Dzieła podejmują apostolstwo. Pierwszy z nich związany jest z upowszechnianiem posłannictwa św. Josemaríi Escrivy i doktryny całego Kościoła katolickiego. Drugi wiąże się z przekształcaniem struktur społecznych ${ }^{13}$.

Ewangelizacja, którą każdy członek Prałatury indywidualnie czyni w swoim codziennym otoczeniu, jest najważniejszym rodzajem apostolstwa Opus Dei. Opiera się ono na świadectwie i dawaniu własnego przykładu; jest ufundowane na przyjaźni, zaufaniu i dyskrecji. Inny rodzaj apostolstwa wiąże się z organizowaniem przez Prałaturę „dni skupienia”, „rozważań duchowych” czy tak zwanych „kręgów”. Działania te mają wymiar instytucjonalny (choć ujawniają się tu także nieformalne przejawy apostolstwa praktykowane w komunikacji międzyludzkiej) i gromadzą różne kategorie osób z podziałem na wiek, płeć i stan cywilny.

Szczególnymi odmianami apostolstwa instytucjonalnego są przedsięwzięcia związane z pracą zawodową członków Dzieła. Niekiedy wierni Prałatury, razem z osobami spoza Opus Dei, podejmują wspólną działalność apostolska, tworząc środowiska, które promieniują duchem chrześcijańskim. Inicjatywy te usiłują przyczynić się do rozwiązania aktualnych problemów dotykających społeczności, zwłaszcza w dziedzinie edukacji, kształcenia zawodowego, pomocy społecznej, opieki lekarskiej i sanitarnej (przy czym

10 J. Escrivá, Bruzda, Poznań 2013, nr 452.

${ }^{11}$ V. G. Hoz, Ideas para la educatión. Tras las huellas del beato Josemaría, Madrid 2001, s. 13, niepublikowane thumaczenie polskie.

12 Tamże, s. 16.

13 Por. J. Domaradzki, dz. cyt., s. 262. 
nie mają one charakteru biznesowo-ekonomicznego, który po prostu nie wiąże się z podstawowymi celami Prałatury). Dzieła, o jakich mowa, powstają i rozwijają się zgodnie z prawem cywilnym poszczególnych państw. Samo Opus Dei natomiast - co zaznacza D. le Tourneau - nie bierze nawet pośredniej odpowiedzialności za przedsięwzięcia apostolskie, które są jednocześnie pracą zawodową jego członków. Wierni Prałaturze są w tym wypadku osobiście odpowiedzialni za swoją działalność i wykonywanie pra$\mathrm{cy}^{14}$. W założeniu przedsięwzięcia te nie są przeznaczone dla wąskiego kręgu osób związanych z Dziełem lub skierowane jedynie do członków Kościoła katolickiego - ich beneficjentem może być każdy, również niewierzący (por. rozdział 3.1). G. Romano dodaje, że są projektami - ,inicjatywami obywatelskimi i profesjonalnymi, za które promotorzy biorą odpowiedzialność wobec innych ludzi i państwa"15. To samo dotyczy pracy kapelanów sprawujących posługę duszpasterską przy zakładanych placówkach - działają oni we własnym imieniu i nie reprezentują Prałatury Opus Dei ${ }^{16}$.

Często dyskutowanym tematem jest kwestia przynależności wspomnianych przedsięwzięć. Podając za J. Domaradzkim: o ile władze Prałatury podkreślaja, że nie są one „własnością" Opus Dei, które sprawuje nad nimi jedynie ,duchową opiekę” (art. $121 \S 2,122$ ) i odpowiada za „duchową i doktrynalną formację" chętnych oraz posługę kapłańską w kaplicach znajdujących się przy nich (art. 122-123), o tyle w myśl założeń pozytywnej krytyki, stwierdzić należy pewną nieścisłość w takim postawieniu sprawy. Istotnie - zauważa autor - znaczna część inicjatyw powstaje bez udziału Opus Dei rozumianego jako organizacja, jednak inne inicjatywy nie są możliwe do zrealizowania bez aktywnego udziału samych władz Prałatury. Nie zmienia to jednak faktu, że z czasem sami członkowie Dzieła przejmują nad tymi przedsięwzięciami znaczną kontrolę, a udział ogranicza się do zapewnienia „formacji duchowej” dla pragnących wziąć w nich udział ${ }^{17}$. Krytycy Opus Dei zwracają jednak uwagę na zapis Artykułu 122. § 2 Statutów, który mówi zarówno o przedsięwzięciach Opus Dei, jak i tych rozwijanych przez wiernych Prałatury. Argumentują ponadto, że realizacja wielu z inicjatyw została powierzona numerariuszom i numerariom, czyli członkom Opus Dei sensu stricto, którzy znajdują zatrudnienie przy wspomnianych dziełach apostolskich. Cytowany już J. Domaradzki stwierdza zaś, że należałoby uznać za błędny pogląd krytyków, uznających przedsięwzięcia za w pełni zarządzane

14 Por. D. le Tourneau, Czym jest Opus Dei, Warszawa 2004, s. 126, 143.

15 G. Romano, dz. cyt., s. 174.

${ }^{16}$ Por. strona szkoły Stowarzyszenia Sternik, http://www.sternik.edu.pl, zakładka Tożsamość chrześcijańska.

17 J. Domaradzki, dz. cyt., s. 268. 
przez Opus Dei w jego wymiarze organizacyjnym. Podkreśla, że należy odróżnić Opus Dei jako pewną ideę od zjawisk uwarunkowanych nią, to jest będących skutkami dzieł apostolstwa w praktyce społecznej ${ }^{18}$.

Kierujący dziełami starają się wszechstronnie rozwijać osobowość tych, którzy w nich uczestniczą - poprzez wzrastanie w cnotach, takich jak sprawiedliwość, odpowiedzialność, szacunek dla innych ludzi, solidarność, prawdomówność, pracowitość, roztropność czy lojalność. Inicjatywy te stwarzają przestrzeń, w której osoba kształtuje się we współistnieniu z innymi, w duchu braterstwa, wzajemnej szczerości i hojności. Tak właśnie wyraża się w praktyce pedagogia nauczania św. Josemaríi Escrivá, u podstaw której znajduje się pojęcie „dziecięctwa Bożego” jako czynnika ukierunkowującego chrześcijanina na nowy sposób bycia i działania.

Istnieje wiele inicjatyw apostolskich prowadzonych przez członków i współpracowników Opus Dei w naszym kraju. Większość z nich podejmowana jest indywidualnie, w środowiskach poszczególnych osób jako wynik ich miłości do Kościoła. Jak wspominałam, jest to najważniejszy rodzaj apostolstwa w Opus Dei. W niniejszym artykule zamierzam jednak skupić się na tych dziełach apostolskich, które mają wymiar instytucjonalny i istnieją w społeczeństwie jako organizacje.

\section{Wybrane dziela apostolskie}

\subsection{Przedszkola i szkoły Stowarzyszenia "Sternik"}

Kształtowanie człowieka nie polega jedynie na nabywaniu określonej wiedzy, ale na wyrabianiu zdolności wartościowania i porządkowania poszczególnych elementów poznania. Współczesne praktyki edukacyjne zauważa V. G. Hoz - mają jeden poważny brak: nie przywiązują wagi do osobistej refleksji oraz „mądrości serca”, które uwypukliliśmy jako części składowe kontemplacji (rozdział 1). Teoria kontemplacji nadprzyrodzonej została przez Escrivę połączona ze zwykłymi funkcjami ludzkiego myślenia. Każdy akt edukacyjny rozbudza i ukierunkowuje ludzką inteligencję. Jeżeli poznanie pozostanie na powierzchownym poziomie rzeczy, to może służyć jako podstawa do określonych działań o charakterze materialnym czy technicznym. Jeśli jednak osoba próbuje poznać przyczyny istnienia, odkryć, dlaczego coś się robi albo czegoś nie robi, jeżeli wreszcie odkryje wartość, jaką mają dla niej te czy inne czyny, to wtedy rozum przeniknie materialny świat otaczających nas rzeczy w sposób głęboko ludzki - duchowy. Innymi

\footnotetext{
18 Por. tamże.
} 
słowy, pedagogika inspirowana nauczaniem Założyciela Opus Dei postuluje zintegrowanie rozwoju woli i serca. Integralność i spójność zaś to - zdaniem Świętego - podstawowe warunki rzutujące na jakość edukacji ${ }^{19}$.

„Zakładajcie szkoły dla swoich dzieci, szkoły będące przedłużeniem domu rodzinnego, w którym praktykuje się ducha służby, współpracy, hojności, jedności”20. W 2003 roku grupa rodziców, zainspirowana powyższymi słowami św. Josemaríi Escrivá, zawiązała Stowarzyszenie Wspierania Edukacji i Rodziny „Sternik”, którego celem było uruchomienie placówek edukacyjnych, opartych na ścisłej współpracy z rodzina, tak aby zachować spójność pomiędzy wychowaniem w domu, a tym, jakie dzieci otrzymują w zewnętrznych środowiskach edukacyjnych. Chodziło o to, by każdy element edukacji współdziałał i umacniał pozostałe elementy, a nie stanowił dla nich przeszkody ${ }^{21}$. Założenie to odnosi się do podkreślanego przez twórcę Opus Dei postulatu jedności życia, który czyni ludzką egzystencję bardziej owocną. O nadzór merytoryczny oraz przekazanie doświadczeń w organizowaniu i prowadzeniu tego typu inicjatyw Stowarzyszenie zwróciło się do hiszpańskiego Institució Familiar d'Educació (IFE), który od 1969 roku kieruje 13. tak profilowanymi placówkami.

Pierwszymi i głównymi wychowawcami dzieci, zarówno w tym, co ludzkie, jak i w tym, co nadprzyrodzone, są rodzice ${ }^{22}$. Dlatego promowany przez Stowarzyszenie system wychowawczy opiera się na porządku: rodzice - nauczyciele - dzieci. Porządek ten oznacza, że odpowiedzialność za wychowanie dziecka ponoszą w pierwszym rzędzie ci, którzy powołali je na świat, następnie kadra pedagogiczna, która wspiera rodziców w tym zadaniu i wreszcie - sami uczniowie ${ }^{23}$.

Realizowany przez „Sternika” model wpisuje się w nurt edukacji spersonalizowanej. Indywidualny charakter procesu kształcenia, uwzględniający dobro całej osoby, wymaga, aby każde działanie o charakterze edukacyjnym miało bezpośredni lub pośredni związek z doskonaleniem się człowieka. W wychowaniu całościowym chodzi o zwrócenie szczególnej uwagi na kształtowanie cnót w pięciu obszarach. Są nimi: rozum, wola, emocje, ciało oraz duch. Wyrazami tych cnót są odpowiednio: dążenie do prawdy, dążenie do dobra, radość z czynienia dobra, doskonalenie narzędzia czynienia dobra, jakim jest ciało, otwarcie na transcendencję oraz nawiązanie osobistej relacji

\footnotetext{
19 Por. V. G. Hoz, dz. cyt., s. 17, 54.

20 P. Zuchniewicz, Sternik - coś więcej niż szkoła, „Nasz Józefów” 3 (2011), s. 4.

21 Por. V. G. Hoz, dz. cyt., s. 53.

22 J. Escrivá, To Chrystus przechodzi, Katowice-Ząbki 2003, nr 27, s. 88.

23 www.sternik.edu.pl, zakładka Szkoła rodzin.
} 
z Bogiem i z innymi ${ }^{24}$. Każdy miesiąc w przedszkolu lub w szkole przeznaczony jest więc na kształtowanie innego nawyku lub cnoty z trzech obszarów: socjalizacja, praca, autonomia, adekwatnie do wieku dziecka.

Szkoły „Sternika” są zróżnicowane ze względu na płeć - w osobnych szkołach uczą się dziewczęta, w osobnych chłopcy. Edukacja zróżnicowana uwzględnia i wykorzystuje w procesie kształcenia naturalne różnice rozwojowe - biologiczne, psychiczne i społeczne istniejące pomiędzy obiema płciami. Wymaga jednak odpowiednio przygotowanej kadry, a także stosowania zróżnicowanych metod pracy dydaktycznej. Nie jest zatem rozwiązaniem wyłącznie organizacyjnym, lecz systemowym ${ }^{25}$.

Innym narzędziem edukacji spersonalizowanej jest tutoring. Każda rodzina biorąca udział w omawianym projekcie otrzymuje tutora - szkolnego opiekuna dziecka i rodziny, z którym regularnie spotyka się, by omawiać kwestie związane z rozwojem dziecka oraz jego funkcjonowaniem w grupie rówieśniczej. Rodzice wraz z tutorem we wspólnym dialogu dochodzą do konkretnych ustaleń, a ich realizację weryfikują podczas następnego spotkania. Co ważne, nie tylko przed dziećmi jako uczniami stawia się określone wymagania, lecz również rodzice i nauczyciele starają się wzrastać w cechach, jakich oczekują od najmłodszych. Nie można bowiem uczyć tego jak pisał św. Josemría - czego sami nie praktykujemy bądź przynajmniej nie staramy się praktykować ${ }^{26}$. W myśl tych założeń o „Sterniku” należy mówić jako o projekcie, w którym biorą udział całe rodziny.

Z założenia do „Sternika” może dołączyć każda rodzina, o ile możliwe jest porozumienie i elementarna zgodność poglądów między nią a przedszkolem bądź szkołą. Koszt nauki dziecka we wspomnianych stanowi jednak dla wielu rodziców barierę. Oprócz czesnego należy także: wykupić udziały w spółce „Rodzice dla Szkoły” (RDS), której głównym celem jest gromadzenie kapitału na budowę i rozwój infrastruktury placówek edukacyjnych, oraz wnieść darowiznę, będącą materialnym potwierdzeniem woli włączenia się rodziny w inicjatywę. Rodzice mniej zamożni mogą starać się o tak zwane ,indywidualne ustalenie wysokości czesnego" i w miarę możliwości otrzymać wsparcie ze środków Funduszu Edukacyjnego. Wysokość opłat za naukę, przykuwające uwagę infrastruktura i kompleksy budynków, jak również atrakcyjność i innowacyjność zajęć edukacyjnych, sprawiają jednak, że środowisko „Sternika” bywa posądzane o ekskluzywizm, elitaryzm czy two-

24 Por. tamże, zakładka Wychowanie osoby.

25 Zob. na ten temat: E. Vidala (red.), Równi ale różni. Perspektywy edukacji zróżnicowanej, Warszawa 2007, s. 17.

26 Por. J. Escrivá, Kuźnia, Katowice-Ząbki 2007, nr 694, s. 256. 
rzenie ,enklaw dla bogaczy”27.

Według oficjalnie podawanych informacji, omawiane przedszkola i szkoły nie maja charakteru wyznaniowego a zaangażowanymi w Projekt mogą być również osoby niewierzące bądź innej niż chrześcijańska religii. Nie sposób jednak nie zauważyć, iż w centrum działań „Sternika” znajduje się katolickość, a wychowanie religijne jest stałym i ważnym elementem programów i planów zajęć. Uczniom i rodzicom proponuje się formację duchową opartą na nauczaniu Kościoła katolickiego oraz inspirowaną życiem św. Josemaríi Escrivy. Zachęca się rodziców do wspólnego uczestnictwa w naukach i spotkaniach o tematyce wychowawczo-religijnej, a także do praktykowania wiary w życiu codziennym. Sytuację tę następująco komentuje Założyciel Dzieła:

Muszę wyznać [...], że nie sympatyzuję z wyrażeniami szkoła katolicka, szkoły kościelne itp., choć szanuję zdanie innych. Wolę, by o rzeczywistości mówiły owoce, nie nazwy. Szkoła wtedy będzie rzeczywiście chrześcijańska, gdy równa innym zadba o poziom nauczania, da wychowankom wykształcenie kompletne - również chrześcijańskie - chroniąc wolność osobistą i podnosząc palące potrzeby sprawiedliwości społecznej. Jeśli to właśnie czyni, nazwa nie ma znaczenia. Powtarzam, osobiście wolę unikać tych przymiotników ${ }^{28}$.

Obecnie w Polsce w ramach Stowarzyszenia „Sternik” działają: przedszkola i szkoły podstawowe dla dziewcząt i chłopców w Krakowie, Poznaniu, Nadarzynie i Warszawie-Józefowie, gdzie ponadto znajduje się gimnazjum i liceum dla dziewcząt oraz gimnazjum dla chłopców. Tworzą one rodzinę z blisko 500 placówkami w $38 \mathrm{krajach}^{29}$, które promują ten typ edukacji na całym świecie.

\subsection{Ośrodki edukacyjno-kulturalne}

Wiele działań apostolstwa prowadzonych jest poprzez powstałe w tym celu ośrodki stowarzyszeń kulturalno-oświatowych, które opieką duszpasterską objęła Prałatura Opus Dei.

W 1996 roku w Bożej Woli (miejscowość k. Mińska Mazowieckiego) rozpoczęło działalność Stowarzyszenie Podnoszenia Kwalifikacji Kobiet (SPKK). W jego powstanie zaangażowana była liczna grupa osób, zarówno

${ }^{27}$ Zob. http://www.sternik.edu.pl/faq

28 J. Escrivá, Rozmowy z Prałatem, nr 81, s. 196-197.

${ }^{29}$ www.sternik.edu.pl, zakładka $O$ nas. 
członków Opus Dei, jak i ludzi niezwiązanych z Dziełem, lecz dostrzegających potrzebę powstania takiego ośrodka. SPKK podejmuje zadania na polu szeroko rozumianej poprawy statutu społecznego i zawodowego kobiet. Do jego celów należą: podkreślanie ważności zawodów związanych z pracami domowymi ${ }^{30}$, inicjowanie i wpieranie działalności oświatowej, naukowej i kulturalnej zmierzającej do pielęgnowania tradycji rodzinnych, a także wszechstronne wspieranie rozwoju szczególnie młodych kobiet w oparciu o tradycje kultury chrześcijańskiej.

Przez ostatnie kilkanaście lat Stowarzyszenie to wielokrotnie pełniło rolę organizacji inicjującej lub wspierającej projekty edukacyjno-kulturalne, które po osiagnięciu samodzielności organizacyjnej zostały przekazane w zarządzanie oddzielnym stowarzyszeniom. Lista obecnie działających projektów obejmuje ośrodki: „Wisła” i „Filary” w Warszawie, „Bursztyn” w Szczecinie, „Skała” w Krakowie, „Panorama” we Wrocławiu oraz „Antrejka” w Poznaniu. Męską gałąz dla działalności apostolskiej stanowią ośrodki: „Na Skarpie”, „Przy Filarowej”, „Potok” i „Wawer” w Warszawie, „Rejs” w Szczecinie, „Sołek” w Poznaniu oraz „Barbakan” w Krakowie.

W ośrodkach można skorzystać z szeroko rozumianej formacji kulturalnej, jak i religijnej. Odbywają się tu: wykłady - głównie z zakresu nauk filozoficznych i społecznych, katechezy, kursy doktrynalne, językowe czy dotyczące umiejętności praktycznych, warsztaty - na przykład dziennikarskie, programowania, kulinarne, z dziedziny mody etc. oraz spotkania z ciekawymi ludźmi. Opracowuje się w nich projekty wolontariatu, realizowane w kraju bądź za granica. Zainteresowani mogą ponadto skorzystać z posługi kapłana, prosić o kierownictwo duchowe, uczestniczyć w nabożeństwach, rozważaniach duchowych lub $\mathrm{w}$ dniach skupienia (podobna praca apostolska podejmowana jest także w miastach, w których nie istnieją ośrodki, a w których zebrała się grupa osób pragnących formować się w duchu Opus Dei; osoby te mogą liczyć na opiekę duszpasterską kapłana związanego z Dziełem, który regularnie odwiedza zbierającą się w określonym miejscu grupę, prowadzi lekcje i spotkania modlitewne.

W 2001 roku SPKK we współpracy z Podlaskim Towarzystwem Oświatowo-Kulturalnym „Potok” uruchomiło Centrum Konferencyjno-Formacyjne „Dworek” w Bożej Woli. Miejsce to służy organizacji rekolekcji,

${ }^{30}$ Ks. Josemaría następująco wypowiadał się o jednej ze szkół-rezydencji w Madrycie dla przyszłych gospodyń domowych: „Głównym celem [tego Stowarzyszenia] jest podkreślenie godności zawodu gospodyni domowej, w ten sposób, aby mogła wykonywać swą pracę z podejściem naukowym. Mówię „,z podejściem naukowym”, ponieważ jest konieczne, aby praca w domu była traktowana jako prawdziwy zawód". J. Escrivá, Rozmowy z Prałatem, $\mathrm{nr} 109$. 
cykli wykładów, kursów i szkoleń oddzielnie dla kobiet i mężczyzn. Rocznie z oferty „Dworku” korzysta około 1000 osób, w tym także gości z zagranicy ${ }^{31}$.

Infrastruktura „Dworku” umożliwiła stworzenie projektu Ośrodka Kształcenia Kobiet Wiejskich. Ośrodek pretenduje do bycia w przyszłości miejscem, gdzie kobiety ze środowisk wiejskich, niezależnie od wieku, będą mogły otrzymać wykształcenie niezbędne do rozwoju zawodowego i samozatrudnienia. Planowane jest uruchomienie kursów hotelarstwa, agroturystyki oraz turystyki wiejskiej. Zlokalizowanie ośrodka w Bożej Woli, $50 \mathrm{~km}$ na południowy wschód od Warszawy, na trasie Warszawa-Terespol, pozwoli na organizowanie zajęć również dla osób zamieszkujących wschodnie obszary przygraniczne ${ }^{32}$.

W ośrodkach edukacyjno-kulturalnych, obok tworzenia warunków dla zdobywania wiadomości oraz umiejętności zawodowych, zwraca się uwagę na nabywanie kryteriów wartościowania, rozwijanie cnót i cech, których wymaga ludzka godność. Cnoty te są nie tylko zlepkiem luźnych wartości, ale stanowią spójną całość, którą autorzy nazywają conexio virtutum i o której św. Jan od Krzyża powiedział: „wszystkie cnoty wzrastają przy ćwiczeniu jednej”33. Działania ośrodków szczególnie ukierunkowane są na kształtowanie woli, której zagadnienie ściśle związane jest z programem wychowania. Jak pisał Założyciel Opus Dei, wolność jest między innymi zdolnością „wyboru życia" ${ }^{34}$. Jej kompetencją - podaje V. G. Hoz - jest decydowanie, ale potrzebuje ona poznania, aby odróżnić to co dobre od tego co złe. Zdaniem wspomnianego autora, kształcenie woli obejmuje dwie duże grupy celów: nabycie kryteriów oceny moralnej oraz przyswojenie nawyków woli, którym odpowiadają nauczanie etyczne oraz praktyczne przyzwyczajenia zarówno w małych drobnych czynnościach dnia codziennego, jak i w sprawach o większym zasięgu. Ważną podporą woli jest inteligencja; kształtowanie woli wieńczy zaś i usprawnia formację intelektualną ${ }^{35}$. Wspólnota życia i spontaniczne relacje między wychowującymi a korzystającymi z formacji sprzyjają budowaniu kryteriów oceny moralnej, które przyczyniają się do tworzenia życiowych postaw i światopoglądów.

Obok przedstawionego wzorca funkcjonowania omawianych instytucji, istnieją w społecznym przekazie poglądy krytykujące działania ośrodków. To, co zdaniem jednych wynika $\mathrm{z}$ wiary i pragnienia głoszenia jej wśród in-

31 www.opusdei.pl/art.php? $\mathrm{p}=42844$

32 Por. http://www.spkk.org.pl/Owczarnia.html

33 Jan od Krzyża, Droga na Górę Karmel, Kraków 2010, ks. 1, rozdz. XII, nr 5, s. 78.

34 Por. J. Escrivá, Przyjaciele Boga, Katowice-Ząbki 2005, nr 24, s. 67-69.

35 Por. V. G. Hoz, dz. cyt., s. 181-183. 
nych, zdaniem drugich nosi znamiona manipulacji czy próby zawłaszczenia człowieka. Jedni widzą w Dziele zaczyn odrodzenia Kościoła katolickiego i powrotu do tradycji, drudzy określają je jako sztywny zbiór obowiązków i wymagań, które przekraczają wolność osoby. Wokół działalności Opus Dei toczy się więc wiele dyskusji. W Polsce na ich intensywność wpływa to, że Dzieło w naszym kraju jest zjawiskiem stosunkowo nowym, a uzyskanie rzetelnej wiedzy o nim wymaga wysiłku. Skrajni przeciwnicy Opus Dei posądzają je o fundamentalizm i posługiwanie się mechanizmami manipulacji. Ich zdaniem ośrodki edukacyjno-kulturalne to nic innego, jak narzędzia do pozyskiwania nowych członków i współpracowników Prałatury; inicjatywy te bowiem sprzyjają nawiązywaniu kontaktów przede wszystkim z młodymi, zdolnymi ludźmi, wśród których upatrywani są potencjalni kandydaci, „podatni na nawrócenie” i ,godni członkostwa w Dziele”. Wspomniane w rozdziale drugim apostolstwo „przyjaźni i zaufania” staje się w tym kontekście elementem metod werbunkowych. $Z$ wybranymi osobami utrzymuje się kontakty, poświęca się im uwagę, czas, darzy troską oraz zaprasza do udziału w licznych przedsięwzięciach po to, by zbliżyć się do osoby i uczynić ją podatną na przekazywane treści.

\subsubsection{Kluby dla dzieci i młodzieży}

W ramach wspomnianych stowarzyszeń kulturalno-oświatowych prowadzone są kluby dla dzieci i młodzieży, zróżnicowane ze względu na wiek i płeć podopiecznych. Ich istnienie wiąże się z troską rodziców korzystających z formacji Dzieła o rozwój swoich dzieci także w obszarze spędzania wolnego czasu. Chodzi bowiem o to, by wszystkie środowiska - rodzinne, szkolne, rówieśnicze - tworzyły jedną, opartą na wspólnych wzorcach przestrzeń wychowawczą. Kluby są zarazem miejscami formacji całościowej młodego człowieka. Oferują bogaty program edukacji nieformalnej, ukierunkowany na wzmocnienie rozwoju naukowego i kulturalnego; rozwijanie zdolności i cech charakteru niezbędnych do dobrego funkcjonowania wśród rówieśników, $\mathrm{w}$ rodzinie oraz $\mathrm{w}$ społeczeństwie (np. dobre wykorzystanie czasu, dbałość o porządek, cierpliwość, prawość, optymizm itp.); rozszerzanie przyszłych możliwości zatrudnienia czy pomoc w rozwijaniu pewności siebie i otwartości na innych. W tych celach wychowankowie klubów: otrzymują wsparcie w procesie planowania i realizowania obranych zamierzen, pomoc przy opracowywaniu planu nauki, uczestniczą w wykładach o tematyce społecznej i dotyczącej rozwoju osobistego, w warsztatach i krótkich kursach zawodowych (np. zarządzania, bioetyki, retoryki, technik komputerowych i programowania, modnego ubierania się, gotowania, prac ręcz- 
nych i wielu innych), w zajęciach sportowych, grach i zabawach, wyjazdach, wycieczkach do muzeów etc. W czasie wakacji klubowicze ponadto moga wziąc udział w kursach językowych, obozach i inicjatywach wolontariatu, razem z innymi młodymi różnych narodowości. Ważnym punktem spotkań klubowych są pogadanki na tematy religijne, medytacje z księdzem lub wspólne modlitwy.

Poprzez liczne zajęcia w klubach młodym stwarza się przede wszystkim przestrzeń, w której mogą oni wzrastać w cnotach - pracowitości, męstwa, sprawiedliwości, radości, dobrego humoru, szlachetności i innych. Zwykłe czynności są okazją do kształtowania nawyków oraz wzrastania w wierze. Proces wychowawczy, tak złożony jak samo życie, wymaga umieszczenia jego celów na najwyższych poziomach ludzkiej doskonałości, ale jednocześnie wymaga ciagłej koncentracji na zwyczajnych sprawach i zadaniach, które dzień po dniu rysują i utrwalają osobowość dziecka ${ }^{36}$.

\subsubsection{Akademiki}

Na czas studiów bądź nauki w liceum młodzież może znaleźć zakwaterowanie w prowadzonych przez stowarzyszenia kameralnych męskich i żeńskich akademikach. Znajdują się one w Szczecinie, Warszawie, Krakowie i Poznaniu.

Idea akademików nawiązuje do tradycji znanych na świecie college'ów uniwersyteckich w USA, Anglii czy Hiszpanii, w których mieszkają zarówno studenci, jak i ich wykładowcy. Dzięki interdyscyplinarności oraz kontaktowi ze studentami różnych kierunków, college stanowi ważną i integralną część wykształcenia, wychowania akademickiego, a także formacji, jaką otrzymują studenci ${ }^{37}$.

Okres studiów, zdaniem św. Josemaríi Escrivá, jest szczególnym czasem dla kształtowania w młodych ludziach poczucia służby społeczeństwu oraz obowiązku przyczyniania się do wspólnego dobra własną pracą zawodową i działalnością obywatelską. W 74 paragrafie Rozmów z Prałatem Escriva czytamy: „Studenci uniwersytetu muszą być odpowiedzialni: winni czuć zdrowy niepokój w obliczu problemów innych ludzi; mieć szczodrego ducha, z którym stawią czoło tym problemom i będą szukać ich najlepszego rozwiązania" 38 .

${ }^{36}$ Cyt. za: V. G. Hoz, dz. cyt., s. 66.

${ }^{37}$ Źródło: strona internetowa Ośrodka „Barbakan” w Krakowie, http://barbakan.edu.pl, zakładka Akademik.

38 J. Escrivá, Rozmowy z Prałatem, nr 74, s. 187. 
Z tego względu naukę traktuje się w akademikach jako ważny obowiązek. Dawniej - jak pisał w Drodze ksiądz Escrivá - „gdy wiedza ludzka była bardzo ograniczona, wydawało się zupełnie możliwe, że pojedynczy uczony może bronić naszej świętej Wiary. Dziś, wraz z rozszerzeniem się i pogłębianiem nauki jest rzeczą konieczną, aby apologeci podzielili między sobą zadanie naukowej obrony Kościoła na każdym polu. - Ty... nie masz prawa wyłączać się z tego obowiązku"39.

Zdobywanie wiedzy to jednak nie jedyna powinność studenta. Josemaría pisał: „Bardzo dobrze, że wkładasz tyle wysiłku w naukę, ale pod warunkiem, że z takim samym wysiłkiem będziesz starał się o zdobycie życia wewnętrznego" ${ }^{40}$. „Konieczny jest również rozwój twojej duszy. Wówczas będziesz należycie pracował dla Chrystusa [...] i pełnił apostolstwo”"41. „Studencie! Kształtuj w sobie solidną i czynną pobożność, wyróżniaj się w nauce, gorąco pragnij być apostołem w swoim zawodzie. - A ja obiecuję ci, iż mocą owej formacji religijnej i naukowej osiagniesz szybko wszechstronny rozwój”“2.

W tych celach rezydentki i rezydenci akademików zapraszani są do udziału we wszystkich przedsięwzięciach organizowanych przez ośrodki - zarówno związanych $\mathrm{z}$ formacją religijna, poznawaniem podstaw doktrynalnych wiary katolickiej, jak i z rozwojem wiedzy, zainteresowań czy umiejętności. Zachęca się ich również do podejmowania własnych inicjatyw sprzyjających tworzeniu życia kulturalno-religijnego w ośrodku. Wszyscy mieszkańcy zobowiązani są ponadto do dbania o rodzinną atmosferę oraz do rozwijania cnót służenia innym, wzajemnej przyjaźni, uprzejmości i szczerości. Pomocne są w tym wspólne posiłki, a po nich spotkania i rozmowy. Studentki i studenci uczą się także dbania o swoje materialne otoczenie poprzez spełnianie drobnych obowiązków, związanych z codziennym funkcjonowaniem domu. Dąży się do tego, by mieszkanie w akademiku było lekcją tego, jak praktycznie realizować wiarę.

Charakter domu studenckiego kształtuje określony styl życia. Dla części osób, szczególnie tych, które wcześniej nie spotkały się z duchowością Dzieła, reguły obowiązujące w akademikach mogą wydać się niezrozumiałe, a nawet zagłuszać przekaz ewangeliczny i głoszone ideały. Mogą doświadczać one poczucia presji, ingerencji w prywatność czy wzmożonej kontroli życia i spędzania wolnego czasu ${ }^{43}$. Starając się zobrazować całość tej sytuacji, posłużę się słowami Z. Korby - jednego z członków Prałatury: „Opus

39 Tenże, Droga, Poznań 2012, nr 338, s. 86.

40 Tamże, nr 341, s. 86.

${ }^{41}$ Tamże, nr 347, s. 87-88.

42 Tamże, nr 346, s. 87.

${ }^{43}$ Nawiązuję tu do wyników badań własnych, przeprowadzonych wśród rezydentek jednego z opisanych akademików w kwietniu 2013 roku. 
Dei jest jak rękawiczka czy kostium, który trzeba przymierzyć. Na niektórych pasuje jak ulał, inni czują się w nim mniej wygodnie, ale doceniają krój czy materiał, inni przymierzają i widzą, że to nie ten fason" ${ }^{44}$.

\section{Akademia Familijna}

Wychowanie dzieci jest najważniejszym zadaniem rodziców ${ }^{45}$. Celem starań wychowawczych matek i ojców powinno być, według nauczania księdza Escrivá, uczynienie dzieci zdolnymi do radości życia. Należy dążyć do tego, by były one uporządkowane wewnętrznie, pracowite i wielkoduszne. Cechy te są bowiem źródłem radości, która osiąga swój ostateczny kształt w perspektywie nadprzyrodzonej, kiedy znajduje swoje oparcie w naszym poczuciu „dziecięctwa Bożego" ${ }^{46}$.

Po to, by wspierać rodziców i pomóc im doskonalić swoje umiejętności wychowawcze, w 2003 roku w Warszawie rozpoczęła działalność Akademia Familijna. Pierwszym etapem prac było przeszkolenie małżeństw, które mogłyby w przyszłości moderować kursy dla rodziców i małżonków. Pieczę nad szkoleniem objęli promotorzy Międzynarodowej Federacji na Rzecz Rozwoju Rodziny (IFFD). Regularne działania Akademii Familijnej rozpoczęły się w 2004 roku kursami w Warszawie, Milanówku, Poznaniu, Gdańsku, Katowicach i Szczecinie, w których łącznie wzięło udział około 100 małżeństw. Następne lata zaowocowały rozwojem tej inicjatywy w kolejnych miastach Polski.

Obecnie Akademia Familijna proponuje kursy dla: małżonków, podczas których mają oni możliwość zweryfikowania aktualnego stanu swojego małżeństwa oraz odkrycia sposobów, w jakie mogą stać się lepszymi osobami, żoną i mężem; dla rodziców dzieci do lat 3, w trakcie których zapoznają się oni z najważniejszymi zasadami wychowania oraz podstawowymi nawykami, jakie dzieci w tym okresie powinny przyswoić; a także dla rodziców dzieci w wieku 4-8 lat - ułatwiające $\mathrm{z}$ jednej strony lepsze poznanie i zrozumienie swoich dzieci - które w tym wieku coraz silniej okazują swoją specyficzną osobowość, wolę i rozum, z drugiej zaś pomagające zindywidualizować podejście do każdego z nich.

Zajęcia prowadzone są z wykorzystaniem metody analizy przypadków (ang. case method), w pracy z tą metodą zasadnicze znaczenie ma aktywny

${ }^{44}$ Portal Na temat, http://natemat.pl/51821,ludzie-opus-dei-dostalismy-wyjatkowydostep-do-czlonkow-organizacji.

45 J. Escrivá, Rozmowy z Prałatem, nr 100, s. 247.

46 V. G. Hoz, dz. cyt., s. 143-145. 
udział uczestników i wkład pracy uczestników, zawsze obojga małżonków. Małżeństwa dzięki analizie przypadków uczą się rozwiązywania typowych problemów rodzinnych, by móc reagować z wyprzedzeniem nim wystapia ich symptomy ${ }^{47}$. Działalność Akademii wyraża się również w organizowaniu kongresów i konferencji na temat rodzicielstwa i wychowania, w realizacji projektów publicystycznych oraz wydawniczych, a także w licznych indywidualnych przedsięwzięciach jej członków.

\section{Zakończenie}

Nie sposób zaprzeczyć, że środowisko skupione wokół dzieł Opus Dei posiada duży potencjał wychowawczy. W założeniach przedsięwzięć apostolskich podejmowanych przez wiernych i współpracowników Prałatury przejawia się ogromny szacunek dla życia intelektualnego, jaki charakteryzował księdza Escrivá. Prałat Josemaría był bowiem świadomy wzrastającej roli edukacji w podlegającym głębokim przemianom społeczeństwie europejskim XX wieku. Jego zdaniem, edukacja jest drogą do chrześcijańskiej doskonałości ${ }^{48}$. Integruje ona $\mathrm{w}$ człowieku to, co indywidualne. $\mathrm{z}$ tym, co społeczne; jak pisali V. G. Hoz i G. Romano, daje skutki zarówno na poziomie jednostkowym, jak i ,angażuje osoby w kontakcie z innymi ludźmi”"99.

$Z$ jednej strony Opus Dei dąży więc do kształtowania pożądanego typu osobowości, w wymiarze holistycznym, obejmującym wszystkie aspekty życia (ascetyczny, apostolski, rodzinny, społeczny i zawodowy), z drugiej zaś Dzieło jawi się jako projekt zmierzający do przekształcenia rzeczywistości społeczno-kulturalnej. Ukształtowani zgodnie z Duchem Dzieła wierni przysposobieni są do tego, by przeciwstawiać się współczesnym trendom laicyzacji, bezkrytycznemu pluralizmowi i różnym przejawom relatywizmu. Znajdują oni motywację do bycia ewangelicznym zaczynem, zdolnym oczyszczać i przemieniać ludzkie środowiska.

Działania wiernych Opus Dei nie są skierowane przeciwko procesom modernizacyjnym. Dzieło zostało powołane do tego, by w duchu ewangelicznym i we współpracy z Łaską Bożą odnawiać to, co zostało stworzone. W centrum chrześcijaństwa znajduje się bowiem tajemnica Wcielenia Syna Bożego, która jest wyrazem przyjęcia świata w jego totalności. Aktywni

${ }^{47}$ Por. A. Hardt, Nauka świętego Josemarii o rodzinie to nie tylko słowa, w: J. Perszon, P. Roszak (red.), Namiętnie kochać świat. Teologia laikatu wedlug św. Josemaríi Escrivy (1902-1975), Toruń 2012, s. 218.

48 V. G. Hoz, dz. cyt., s. 94-95.

${ }^{49}$ Por. tamże, s. 124; G. Romano, dz. cyt., s. 174. 
chrześcijanie - wśród których wielu jest członkami Prałatury - wskazują w nowoczesności miejsce dla bogatej, żywej tradycji katolickiej, a przez to pomagają łączyć rozwój wiedzy, charakter i zadania instytucji społecznych z celami i wskazaniami katolickiej nauki społecznej,oraz osiągnięciami myśli chrześcijańskiej. Podobnie jak w przypadku całego Kościoła, wpływ Opus Dei w społeczeństwie nie ma przy tym charakteru doczesnego - choć znajduje on swoje odbicie w aspektach etycznych wszelkiej działalności ludzkiej - ale ponadczasowy, wyższy, który wyraża się czasownikiem: „uświęcać”50.

\section{Apostolic Works according to the Spirit of Opus Dei (Summary)}

This article discusses the issue of the apostolate of members and cooperators of the Prelature of Opus Dei. It situates the apostolate in the Opus Dei doctrine and indicates its significance. This text focuses on the presentation of selected institutional apostolic works within Poland. It refers to extracts of the writings of Josemaría Escrivá, who justifies the need for the existence of these initiatives and stresses their educational and formative character. The activities of the mentioned organizations are presented in the context of social role of religion and the project of social structures transformation.

Keywords: Opus Dei; apostolate; apostolic works; social role of religion.

\section{Dziela apostolskie w duchu Opus Dei (Streszczenie)}

Artykuł podejmuje temat apostolstwa członków i współpracowników Prałatury Opus Dei. Umiejscawia apostolstwo w doktrynie Opus Dei i wskazuje na jego znaczenie. Tekst skupia się na zaprezentowaniu wybranych dzieł apostolstwa instytucjonalnego na terenie Polski. Odwołuje się do fragmentów pism św. Josemaríi Escriy, które uzasadniają potrzebę istnienia tych przedsięwzięć oraz eksponuje ich edukacyjno-formacyjnych charakter. Działania wspomnianych organizacji przedstawia w kontekście społecznej roli religii i projektu przekształcenia struktur społecznych.

Słowa kluczowe: Opus Dei; apostolstwo; dzieła apostolskie; społeczna rola religii.

50 J. Escrivá, Rozmowy z Prałatem, nr 18, s. 60-61. 
